\title{
Using Lecture Videos in Flipped Classroom Model
}

\author{
Bui, Thi Kim Loan ${ }^{1 *}$ \\ ${ }^{I}$ Faculty of Foreign Languages, Van Lang University \\ *Corresponding author's email: loan.bt@vlu.edu.vn
}

\begin{abstract}
Due to the Covid-19 pandemic, traditional teacher-centered teaching has been replaced with learner-centered teaching models. The flipped classroom model has been considered effective by the researchers in the circumstance in which both teachers and students are not able to be present in physical classrooms because of strict Covid-19 prevention regulations; instead, they both teach and study online from flipped classrooms approach. This paper aims to investigate the usage of lecture videos in flipped classroom model in order to clarify what teachers and learners need to do to utilize instructional videos effectively in online classrooms. There has been an argument that the teachers should deploy YouTube videos or they should produce their own lecture videos for flipped classrooms. The paper also reviews previous studies related to the utility of lecture videos in the flipped-classroom approach to shed light on lecture videos in flipped classrooms. From the findings on using lecture videos in flipped classroom model, the paper gives some implications for using instructional videos and suggestions for future research on lecture videos in flipped classrooms.
\end{abstract}

Keywords: learner-centered teaching models, flipped classroom, lecture videos, online classroom.

\section{INTRODUCTION}

The flipped classroom model has revolutionized teachers' teaching methodology and learners' learning styles. Very little research has been focused on using the lecture videos in the flipped classroom model in Vietnamese higher education. Instructional videos are beneficial to both teachers and learners when they shift from traditional classrooms to online classrooms. This research aims to investigate the usage of lecture videos in the flipped classroom at Van Lang University, which has been recently transiting from the traditional teaching and learning model to teaching and learning, which are based on flipped classroom principles.

In the context of Vietnam, the flipped classroom has not been appropriately implemented at several high schools and universities so far. The creation and application of computer-mediated teaching materials or Information and Communication Technology (ICT) have significant impacts on language learner autonomy [1-3]. The growing implementation of using instructional videos in the flipped classroom has clearly changed English as a foreign language (EFL) teaching and learning methodologies. A great number of researchers admit that the usage of technology helps FL learners study English better and faster because they can manage their learning at their own pace and time (ibid). This motivates EFL learners to study online anywhere and anytime. There have been a great number of instructional videos on YouTube from EFL learners who can gain access to learning English. It is, nevertheless, argued that instructional videos made by teachers are more effective than those on YouTube in the flipped classroom. This argument can be explained by the fact that it depends on the aims of lessons so that teachers can choose instructional videos made by teachers or YouTube videos to spread knowledge to the learners who need to be exposed to much English naturally and communicatively. Therefore, to seek plausible answers to such problems, this study, within the limitation of this research, endeavors to scrutinize the advantages and disadvantages of using instructional videos for EFL learners' online learning in the flipped classroom model. The following research question must be addressed:

What are the advantages and disadvantages of using lecture videos for EFL learners' online learning in the flipped classroom model?

\section{LITERATURE REVIEW}

\subsection{Flipped classroom approach}

Bergmann and Sams (2012:13) [4] describe flipped learning and teaching as an effective strategy because "traditionally done in class is now done at home, and 
what was traditionally homework is now done at home."

These authors flipped their chemistry classes in 2007 by recording their lectures and requiring their students to watch these instructional videos at home, and spending classroom time working on practical problems.

The flipped classroom model/approach has gained in popularity in recent years. The Khan academy channel has been well-known for producing free educational videos hosted on YouTube since 2011. This channel has inspired a great number of teachers of different subjects at high schools and universities who adopted this flipped approach to encourage learners' online learning all over the world.

The terms 'flipped learning' and 'flipped classroom' can be used interchangeably, and the former term focuses more on learning than teaching. Hockly (2017) [5] develops the flipped approach and argues that flipped learning does not necessarily involve watching videos online before the students come to the class, and therefore it is regarded as a form of blended learning.

The flipped approach has emphasized the learner's learning. Phrases such as 'learner-centered or 'studentcentered are used to describe this approach, which has recently motivated several English language teaching (ELT) teachers to explore the potential of flipped learning. According to Part of the Cambridge Papers in ELT series (2020) [6], there are a lot of potential advantages of flipped learning, including (1) personalization, (2) active learning, and (3) engagement and attitudes. First, personalization includes helping with specific difficulties, self-pacing, offering a personal choice of study material, and providing individual support. Second, active learning consists of focusing on higher-order skills, facilitating increased interaction between students, and creating more opportunities for useful feedback. Finally, engagement and attitudes comprise addressing classroom management issues, encouraging learner 'ownership' of learning, and promoting a contract between school parents/carers.

In general, Bergman and Sams (2012:2) assert that "the flipped classroom can address the needs of students $[\ldots]$ by allowing their teachers to personalize the students' education". Moreover, Kosta and Marshall (2017:227) [7] point out that the 'higherorder skills of analyzing, evaluating and creating are developed in the flipped classroom because the learners spend more time-solving problems, discussing, working collaboratively, and thinking critically spontaneously (Johnson \& Marsh (2016) [8]. The flipped classroom encourages learners' activeness, which leads to effective learning. Mercer and Dörnyei (2020: 129-141) [9] suggest that to maintain learner's engagement, it is essential to "maximize enjoyment, minimize boredom." They also believe that control and ownership of learning have impacts on learners' engagement.

In the flipped classroom, the teacher's roles have dramatically changed. Ur (2012: 17-18) [10] suggests that teachers should play the role of activator, provider of feedback, supporter, manager, motivator, assessor, instructor, and model.

\subsection{Benefits of using lecture videos in flipped classrooms}

There are great advantages of flipped classroom approach. This model increases interactive communication in class because learners watch lecture videos at home. Preferred flipped learning can be explained by this approach's main aim to provide opportunities for students to communicate and cooperate with their peers and teachers during class time. This mutual collaboration improves meaningful communications. In addition, Voss and Kostka (2019:9-10) [11] reported that the students in the flipped classroom are "engaged in active learning and negotiating meaning." In other words, learners have to work much more in communicative activities in class, and they prepare formal study tasks at home before class.

Also, Fulton (2012) [12] observes that learners can access lecture videos whenever and wherever they are available, and they can learn at their own pace. Herreid and Schiller (2013) [13] find that flipped learning encourages learners to make inventive researches.

Researchers [14-16] have pinpointed the characteristics of learners who self-study. Benson (2007) [14] stated that autonomous learners are extrinsically and intrinsically motivated, which means that they desire achievement and have self-efficacy and positive attitudes for learning. Also, Dickinson (1993) [15] points out some features of independent learners, such as learning new knowledge on their own, setting their own learning goals and strategies, and controlling their learning. Furthermore, Murray 
(2014) [16] mentioned self-access, self-instruction, and self-regulation are three characteristics of autonomous learners. Activeness is also considered as one feature of a learner's autonomy, according to some researchers.

\subsection{The challenges of flipped learning}

Hockley and Dudeney (2017) [17] have reported some challenges of flipped learning, such as noncompletion of assigned work, effective self-regulation, technological issues, and learner and teacher expectations.

A lot of problems will arise when learners in the flipped classroom do not finish doing assigned homework, set their own learning goals, manage their time effectively, and select learning materials appropriately. Besides, the shortage of suitable devices (tablets, laptops, etc.), reliable Internet connections, necessary computer skills influence learners' online learning. Teachers also have some problems with IT skills, digital tools, and hardware when they produce their own learning materials. This is the reason why Kvashnina and Martynko (2016) [18] make learning materials is time-consuming. Moreover, Bristol (2014) [19] reports that some students come to class without preparation and watch lecture videos at home before class. This prevents the implementation of the flipped approach successfully.

Another challenge comes from the learners who are reluctant to shift from teacher-centered models of language learning to flipped classrooms (Kostka \& Marshall, 2017) [ibid] because they think that there will be an increase in workload. Learners should be aware of changes in teaching and learning methods. Moreover, it is advised that school managers should train teachers at the start of the transition to help them overcome some anxieties about new technological skills and negative attitudes towards increased workload.

In brief, it is noticed that most studies focus on using instructional videos in the flipped classroom in various contexts; notwithstanding, the use of lecture videos for EFL learners' online learning has not yet been thoroughly studied. Therefore, this study aims to explore the advantages and disadvantages of using lecture videos for EFL learners' online learning in the flipped classroom model at Van Lang University.

\section{METHODOLOGY}

\subsection{Research site and participants}

This study, which is a mixed-method design, was carried out at Van Lang University. There were 157 fourth-year students who participated in this study. They enrolled in the courses named British and American literature and World Englishes. The courses offered a great deal of knowledge that the participants had to watch lecture videos at home to prepare for the lessons well.

\subsection{Research instruments}

This study employed two instruments, a questionnaire and an interview for data collection. The adapted questionnaire from Nouri (2016) [20] featured some items asking for students' experiences of using video lectures for their online learning. The Cronbach's Alpha was at .78, i.e., the reliability of the questionnaire was reliable. The semi-structured interview was employed for in-depth information and crosschecking the questionnaire's data. There were some open-ended questions asking about students' attitudes towards the advantages and disadvantages of using lecture videos for their online learning in the flipped classroom and their suggestions to improve the effectiveness of using the lecture videos for their flipped learning.

\section{FINDINGS AND DISCUSSION}

\subsection{Results}

\subsubsection{The advantages of using lecture videos for EFL learners' online learning in the flipped classroom model}

Concerning the qualitative data, all of the interviewees showed their agreement that instructional videos play significant roles in their online learning.

\subsubsection{Learning autonomy}

Watching lecture videos at home before class is an effective way to develop the EFL learners' autonomous learning. They reported that they had more time to learn on their own with more lessons to increase their knowledge. Besides, watching lecture videos saved their time for other class activities. They reported that they became more flexible and responsible for their learning. 
Table 1. Learning autonomy

\begin{tabular}{|l|c|}
\hline You can learn by yourself & S56 \\
\hline Students can learn by themselves & S54 \\
\hline More lessons, more self-study, save time & S38 \\
\hline Increase self-study ability & S44 \\
\hline Improve self-study & S9 \\
\hline I have more time to learn by myself & S10 \\
\hline
\end{tabular}

\subsubsection{Controlling of own English learning} activities

The learners controlled their own learning activities, which is efficient. Flipped classroom gave the students more control of their learning and allowed the usage of created materials on a regular basis. They found that lecture videos were convenient because they could watch and pause them many times to take notes.

Table 2. Controlling of own English learning activities

\begin{tabular}{|l|l|}
\hline $\begin{array}{l}\text { Students have more control. Lessons and } \\
\text { content are more accessible. Access means } \\
\text { it is easier for parents to see what's going } \\
\text { on, ... }\end{array}$ & S68 \\
\hline $\begin{array}{l}\text { Students have more control. It can be more } \\
\text { efficient. }\end{array}$ & $\mathrm{S} 74$ \\
\hline $\begin{array}{l}\text { It's more convenient because I can watch } \\
\text { again and pause to take notes }\end{array}$ & $\mathrm{S} 26$ \\
\hline $\begin{array}{l}\text { It gives students more control of their } \\
\text { learning and allows for the usage of the } \\
\text { created materials on a regular basis }\end{array}$ & $\mathrm{S} 73$ \\
\hline $\begin{array}{l}\text { Have more control } \\
\text { Students can know what they will learn in } \\
\text { the next class, so they can prepare before } \\
\text { the class starts. }\end{array}$ & $\mathrm{S} 104$ \\
\hline $\begin{array}{l}\text { In a flipped classroom, students have more } \\
\text { control over their own learning }\end{array}$ & $\mathrm{S} 24$ \\
\hline $\begin{array}{l}\text { A flipped classroom offers students the } \\
\text { benefit of greater control over their } \\
\text { learning. They steer the class discussion to } \\
\text { ask instructors for clarification, so their } \\
\text { needs guide class time. When conducting } \\
\text { hands-on experiments and practicing new }\end{array}$ & \\
\hline
\end{tabular}

\begin{tabular}{|l|l|}
\hline $\begin{array}{l}\text { skills in class, students can have more } \\
\text { autonomy (S64) }\end{array}$ & \\
\hline Students can enhance their motivation & S105 \\
\hline
\end{tabular}

\subsubsection{Avoiding time and psychological pressure}

The majority of learners found less pressure from teachers and time when they watched lecture videos at home for their flipped learning. They felt more comfortable and free because they had more time to prepare lessons and skim lecture videos many times. They found watching lecture videos easy to use, which saved their time. The psychological comfort without being under pressure from teachers and time is important for their flipped learning.

Table 3. Avoiding time and psychological pressure

\begin{tabular}{|l|l|}
\hline More time to prepare the lessons & $\mathrm{S} 63$ \\
\hline More space, more time to skim the lectures & $\mathrm{S} 32$ \\
\hline Less pressure & $\mathrm{S} 110$ \\
\hline It is easy to use and helps me to save time & $\mathrm{S} 17$ \\
\hline $\begin{array}{l}\text { I think it must be the comfort of studying } \\
\text { and the unlimited study time }\end{array}$ & $\mathrm{S} 43$ \\
\hline \begin{tabular}{l} 
I can watch videos many times \\
\hline I can be free
\end{tabular} & $\mathrm{S} 58$ \\
\hline Free & $\mathrm{S} 36$ \\
\hline Comfortable & $\mathrm{S} 125$ \\
\hline $\begin{array}{l}\text { Feel more comfortable without being } \\
\text { under pressure from teachers and time }\end{array}$ & $\mathrm{S} 128$ \\
\hline I am more flexible and responsible & $\mathrm{S} 97$ \\
\hline
\end{tabular}

\subsubsection{Being active and curious to master new knowledge}

The findings indicated that the students became more active and responsible for their learning. They found out the answer to the problems of the lesson, which helped them understand and remember their gained knowledge in the long-term memory. They learned more things from YouTube instructional videos. Besides, they were active when they worked with their peers. 
Table 4. Being active and curious to master new knowledge

\begin{tabular}{|l|l|}
\hline $\begin{array}{l}\text { Students are more active and responsible } \\
\text { for their studies. Students by themselves } \\
\text { find out the questions and problems of the } \\
\text { lesson, which helps them understand and } \\
\text { remember in the long-term memory }\end{array}$ & S67 \\
\hline Learn more & $\mathrm{S} 48$ \\
\hline I learn more things on the Internet & $\mathrm{S} 70$ \\
\hline I can be more active in learning & $\mathrm{S} 3$ \\
\hline Actively working with peers & $\mathrm{S} 7$ \\
\hline Can have more knowledge & $\mathrm{S} 44$ \\
\hline $\begin{array}{l}\text { 4.1.1.5. Motivation and engagement in online } \\
\text { learning }\end{array}$
\end{tabular}

Watching instructional videos at home before class encouraged students to make good preparation to be engaged in online learning. Flipped learning motivated the students to learn effectively because they had to prepare lessons before coming to class.

Table 5. Motivation and engagement in online learning

\begin{tabular}{|l|l|}
\hline More motivation & $\mathrm{S} 11$ \\
\hline $\begin{array}{l}\text { It encourages students to come to class } \\
\text { prepared }\end{array}$ & $\mathrm{S} 72$ \\
\hline $\begin{array}{l}\text { I think students can prepare the lessons } \\
\text { before they go to class }\end{array}$ & $\mathrm{S} 46$ \\
\hline Effective learning & $\mathrm{S} 60$ \\
\hline $\begin{array}{l}\text { It makes better lessons and better learning } \\
\text { Can replay the class and video if you are } \\
\text { away }\end{array}$ & $\mathrm{S} 78$ \\
\hline $\begin{array}{l}\text { There is significant work on the front-end } \\
\text { - Not naturally a test-prep form of } \\
\text { learning. }\end{array}$ & $\mathrm{S} 57$ \\
\hline
\end{tabular}

\subsubsection{Learning at your own pace}

The findings showed that the students could learn at their own pace when they watched lecture videos in flipped learning. They were also given more freedom for self-paced learning, which is more efficient in comparison to traditional classrooms.
Table 6. Learning at your own pace

\begin{tabular}{|l|l|}
\hline Self-paced learning & S71 \\
\hline Learning in my own space & S2 \\
\hline $\begin{array}{l}\text { I can learn at my own pace, be more } \\
\text { efficient }\end{array}$ & S35 \\
\hline $\begin{array}{l}\text { Students are given the freedom to learn at } \\
\text { their own pace }\end{array}$ & S24 \\
\hline
\end{tabular}

\subsubsection{Self-directed learning}

Thanks to watching instructional videos at home before class, the students could promote self-directed learning. This helps them develop more learning skills and makes their learning in class become more bustling.

Table 7. Self-directed learning

\begin{tabular}{|l|l|}
\hline Promote self-directed learning & S1 \\
\hline $\begin{array}{l}\text { Help students have more skills; the class } \\
\text { becomes more bustling }\end{array}$ & S18 \\
\hline
\end{tabular}

\subsubsection{Online interaction between teacher and learners}

The students reported that watching instructional videos at home increased more one-to-one interaction time between teacher and student. The findings revealed that more collaboration time for students encouraged them to come to class with good preparation for lessons. This could improve students' achievement and behavior in class. They found that it was convenient for them to interact with teachers and classmates when they worked together for a class presentation from which they watched lecture videos. They said that watching lecture videos created more motivation for their performance because they learned through visual aids.

Table 8. Online interaction between teacher and learners

\begin{tabular}{|l|l|}
\hline $\begin{array}{l}\text { The more one-to-one time between teacher } \\
\text { and student. More collaboration time for } \\
\text { students encourages students to come to }\end{array}$ & S49 \\
class with good preparation for lessons & \\
\hline $\begin{array}{l}\text { The more one-to-one time between teacher } \\
\text { and student, the more collaboration time } \\
\text { for students }\end{array}$ & S64 \\
\hline
\end{tabular}




\begin{tabular}{|l|l|}
\hline $\begin{array}{l}\text { This can improve student achievement and } \\
\text { improve student behaviour in class }\end{array}$ & \\
\hline $\begin{array}{l}\text { Create more motivation because students } \\
\text { learn through visual aids, etc. }\end{array}$ & $\mathrm{S} 75$ \\
\hline Interaction time may improve performance & $\mathrm{S} 105$ \\
\hline $\begin{array}{l}\text { Can more interact with other friends and } \\
\text { teachers }\end{array}$ & $\mathrm{S} 76$ \\
\hline
\end{tabular}

\subsubsection{The flexibility of learning and accessing} lecture videos

The students found watching lecture videos at home flexible and easily accessed. The lessons and contents were more accessible, and it was easy to take classroom materials. It was also convenient for them to watch lecture videos again if they did not understand the lessons.

Table 9. The flexibility of learning and accessing lecture videos

\begin{tabular}{|l|l|}
\hline More flexible to learn & $\mathrm{S} 77$ \\
\hline Lessons and content are more accessible & $\mathrm{S} 8$ \\
\hline I guess the flexibility in the course & $\mathrm{S} 4$ \\
\hline Easy to take classroom materials & $\mathrm{S} 55$ \\
\hline More flexible to learn & $\mathrm{S} 77$ \\
\hline $\begin{array}{l}\text { Convenient, easy, you can see the lecture } \\
\text { again if you don't understand the lessons. }\end{array}$ & $\mathrm{S} 15$ \\
\hline Easy to access & $\mathrm{S} 32$ \\
\hline Flexibility & $\mathrm{S} 34$ \\
\hline
\end{tabular}

\subsubsection{Time and space convenience}

Watching lecture videos at home was convenient because The student could watch and review them whenever and wherever they wanted to study. The students could learn flexibly at home, at any time, and anywhere. They reported that they had more time to study and understand the lessons more deeply. They had more flexible time and comfortable space to review learning materials.

Table 10. Time and space convenience

\begin{tabular}{|l|l|}
\hline $\begin{array}{l}\text { I can study and review the lecture anywhere, } \\
\text { anytime. It's so convenient. }\end{array}$ & S33 \\
\hline I can learn flexibly at home & S65 \\
\hline
\end{tabular}

\begin{tabular}{|l|c|}
\hline I can learn anytime and anywhere & S42 \\
\hline $\begin{array}{l}\text { Have a lot of time to study and expert their } \\
\text { lesson }\end{array}$ & S27 \\
\hline Flexible time and comfortable space to learn & S76 \\
\hline Flexible & S12 \\
\hline Flexibility & S37 \\
\hline $\begin{array}{l}\text { I am able to do another work at home and } \\
\text { have flexible time for learning }\end{array}$ & S5 \\
\hline $\begin{array}{l}\text { Flexible time and comfortable space to learn } \\
\text { It also allows students who need more time } \\
\text { to take their time to review the materials. }\end{array}$ & S24 \\
\hline \begin{tabular}{l} 
I learn at anytime \\
\hline
\end{tabular} & S26 \\
\hline
\end{tabular}

In short, the qualitative findings indicated that watching instructional videos at home before class in the flipped classroom has a great number of advantages such as (1) learning autonomy, (2) controlling of own English learning activities, (3) avoiding the time and psychological pressure, (4) being active and curious to master new knowledge, (5) motivation and engagement in online learning, (6) learning at own pace, (7) self-directed learning, (8) online interaction between teacher and EFL learners, (9) flexibility of learning and accessing lecture videos, and (10) time and space convenience.

\subsubsection{The disadvantages of using lecture videos for EFL learners' online learning in the flipped classroom model}

In addition to the advantages of using the lecture videos for EFL learners' online learning in the flipped classroom, there are some disadvantages that are reported from the qualitative data.

Firstly, some participants revealed that using lecture videos in flipped learning lacked interaction between teacher and student. They tended to be lazy, unmotivated, and disoriented when there was no faceto-face classroom of watching lecture videos at home.

Secondly, the students sometimes had difficulty comprehending lecture videos at home. They found some questions which were designed to help the students have a purpose of watching the lecture videos hard to answer.

Thirdly, the students needed the teacher's guide on their watching lecture videos at home. Their flipped 
learning was not effective if the students did not have enough guidance from the teacher for what they had to do at home with assignments.

Fourth, few participants reported that they did not receive much knowledge from using instructional videos for their flipped learning. They were afraid of not covering everything for midterm and final tests.

Fifth, few students complained that they prepared a lot for the lessons when they watched the videos at home. They found using lecture videos boring and their time in front of the screen increased. Moreover, they managed their time to participate in the flipped classroom to complete watching the assigned video fully. In my opinion, the reverse classes have to watch PPT and listen to lectures on the screen continuously; it will easily make students tired and bored. Instead, we can design the lecture into a small game, similar to a quiz to attract students more (S61)

Sixth, few students did not have enough skills for self-study. So, they found it hard to watch lecture videos on their own.

Seventh, the participants had some technical problems when they watched the instructional videos on their own. There were also some problems related to access to the internet and technological equipment that both the teacher and the students faced.

Finally, the participants complained about the lack of physical activity in their flipped learning. They spent more time watching lecture videos. This leads to the learner's eye damage and physical tiredness. Some of them complained that their parents were not satisfied with their online learning when they spent too much time watching lecture videos without doing exercise healthily.

Table 11. Disadvantages of using lecture videos

\begin{tabular}{|l|l|}
\hline Interaction & Lack of interaction (S2) \\
\cline { 2 - 3 } & $\begin{array}{l}\text { Teachers need to take more time } \\
\text { to work on students to ensure that } \\
\text { they are in the right way (S56) }\end{array}$ \\
\hline $\begin{array}{l}\text { Students tend to be lazy, } \\
\text { unmotivated, disoriented when } \\
\text { there is no face-to-face } \\
\text { classroom (S60) } \\
\text { You can only take lessons } \\
\text { passively. (can't ask question } \\
\text { right moment you feel confused) } \\
\text { (S68) }\end{array}$ \\
\hline
\end{tabular}

\begin{tabular}{|c|c|}
\hline & $\begin{array}{l}\text { I think teachers should check } \\
\text { messages on Ms Teams (S58) }\end{array}$ \\
\hline & Less interaction (S71) \\
\hline & $\begin{array}{l}\text { Can more interact with other } \\
\text { friends and teachers (S76) }\end{array}$ \\
\hline Collaboration & Lack of peer collaboration (S48) \\
\hline & $\begin{array}{l}\text { Encourage students to prepare } \\
\text { together for classes or exams } \\
\text { (S72) }\end{array}$ \\
\hline Video quality & $\begin{array}{l}\text { sometimes video quality is just } \\
144 p \text {, the sound is not clear, and } \\
\text { it's hard to concentrate on the } \\
\text { video lesson (S3) }\end{array}$ \\
\hline Concentration & $\begin{array}{l}\text { It's a little hard for me to } \\
\text { concentrate (S29) }\end{array}$ \\
\hline & $\begin{array}{l}\text { Sometimes it doesn't work well } \\
\text { for some students who don't } \\
\text { focus on the lesson the other } \\
\text { group has prepared for (S62) }\end{array}$ \\
\hline Comprehensibility & $\begin{array}{l}\text { Sometimes it's hard to } \\
\text { understand (S49) }\end{array}$ \\
\hline & $\begin{array}{l}\text { It's difficult to deal with some } \\
\text { questions (S70) }\end{array}$ \\
\hline Teacher's guide & $\begin{array}{l}\text { It is not effective if students do } \\
\text { not have enough guidance (S53) }\end{array}$ \\
\hline & $\begin{array}{l}\text { Combination between video and } \\
\text { class-time (half-half) (S75) }\end{array}$ \\
\hline Knowledge & Not much knowledge (S55) \\
\hline & $\begin{array}{l}\text { May not cover everything } \\
\text { required for a test (S65) }\end{array}$ \\
\hline $\begin{array}{l}\text { Student } \\
\text { preparation }\end{array}$ & $\begin{array}{l}\text { Relies on student preparation } \\
\text { (S64) }\end{array}$ \\
\hline & $\begin{array}{l}\text { Relies on student preparation, } \\
\text { increased screen time }\end{array}$ \\
\hline & It's boring (S63) \\
\hline & $\begin{array}{l}\text { Students should manage their } \\
\text { time to participate in flipped } \\
\text { classroom and complete full } \\
\text { exercise (S74) }\end{array}$ \\
\hline Skills & $\begin{array}{l}\text { Some students don't have the } \\
\text { ability for self-study (S69) }\end{array}$ \\
\hline $\begin{array}{l}\text { Technological } \\
\text { problems }\end{array}$ & $\begin{array}{l}\text { Need for access to the internet } \\
\text { and technological equipment, } \\
\text { both by the teacher and by the } \\
\text { students, means an accessibility } \\
\text { gap (S67) }\end{array}$ \\
\hline & $\begin{array}{l}\text { It speaks to the technology } \\
\text { generation }(\mathrm{S} 72)\end{array}$ \\
\hline & $\begin{array}{l}\text { Should not ask students that they } \\
\text { must turn on the camera. Not } \\
\text { everyone has a laptop or cam on } \\
\text { the computer (S55) }\end{array}$ \\
\hline
\end{tabular}




\begin{tabular}{|l|l|}
\hline & $\begin{array}{l}\text { Invest in a top-quality digital } \\
\text { platform, .. (S68) }\end{array}$ \\
\cline { 2 - 3 } & $\begin{array}{l}\text { Mostly use technological } \\
\text { devices, requires trust from } \\
\text { teacher and student and obligate } \\
\text { an amount of investment (S66) }\end{array}$ \\
\hline Physical activity & $\begin{array}{l}\text { I think that not all families have } \\
\text { the same communication } \\
\text { infrastructure; not all students } \\
\text { have easy access to get the } \\
\text { teacher's lecture to study and do } \\
\text { some exercises and extras. } \\
\text { Parents will not be satisfied with } \\
\text { their children sitting all day with } \\
\text { phones and computers without } \\
\text { any physical activity (S38) }\end{array}$ \\
\hline
\end{tabular}

Although some students complained about some disadvantages of using lecture videos in their flipped learning and preferred traditional classroom, there were some students who liked flipped classrooms.

\subsection{Discussion}

From the findings, there are some suggestions for using the lecture videos in the flipped classroom. The quality of instructional videos needs to be improved and provided with subtitles (if possible). The participants gave their opinion on the combination of traditional lectures with videos. They thought that there should be some lessons via technological tools such as quizizz or quizlet to motivate them when they watched lecture videos at home alone. Also, the lecture videos should provide more knowledge about the course they are studying. The students should be trained with skills such as soft skills and technology using skills. The participants should learn how to be self-disciplined and to be used to learning with mobile devices.

There should be a better internet connection so that there is no interruption anymore. Lecturers can let students do quizzes; instead they write essays to test self-study knowledge in their flipped learning. Each group must prepare a lesson assigned by the teachers when they watch lecture videos at home (can be divided into different parts for each group) so that this ensures that all groups had read the lesson before class. Finally, the participants also suggested that teachers should give students more useful lessons with videos and images. Therefore, teachers need to be aware of the suggested recommendations from the participants to enhance the effectiveness of instructional videos in the flipped classroom.
This study's results are similar to the findings of Nouri (2016) because this study's findings revealed that the students had positive attitudes towards using instructional videos for their online learning the flipped learning.

\section{CONCLUSION}

It is essential to transit from the traditional classroom to the flipped classroom, especially during the Covid-19 pandemic. Using lecture videos in the flipped classroom is effective. The findings from this study point out the advantages of using instructional videos for EFL learners' online learning in the flipped classroom, such as (1) learning autonomy, (2) controlling of own English learning activities, (3) avoiding the time and psychological pressure, (4) being active and curious to master new knowledge, (5) motivation and engagement in online learning, (6) learning at own pace, (7) self-directed learning, (8) online interaction between teacher and EFL learners, (9) flexibility of learning and accessing lecture videos, and (10) time and space convenience. The benefits of using lecture videos should be implemented in broader contexts in the world.

Although there are some disadvantages of using lecture videos for the learner's learning in the flipped classroom, some suggestions and recommendations are made to increase the effectiveness of watching instructional videos at home before class in the flipped classroom.

There are some limitations of this study. The number of participants is small and they did not have experience flipped learning before; therefore, this will have an impact on the effectiveness of using lecture videos for the learners' online learning. Future studies on the influences of flipped learning should deal with these limitations.

\section{AUTHORS' CONTRIBUTIONS}

This article was written by the author.

\section{ACKNOWLEDGMENTS}

The authors of this article acknowledged the supports of Van Lang University at 69/68 Dang Thuy Tram St. Ward 13, Binh Thanh Dist., Ho Chi Minh City, Vietnam. 


\section{REFERENCES}

[1] T. Q. Tran, The roles of technology in promoting English-majored students' learner autonomy: A critical look at HUTECH context, Proceedings of Conference on Technology and Science 2018 at Ho Chi Minh City University of Technology Ho Chi Minh City: Science and Technology Publishing House, 2018, pp. 344-348.

[2] T. Q. Tran, T. M. Duong, N. T. T. Huynh, Attitudes toward the use of TELL tools in English language learning among Vietnamese tertiary English majors, VNU Journal of Social Sciences and Humanities 5(5) (2019) 581-594. DOI: http://dx.doi.org/10.1172/vjossh.v5i5.498.

[3] T. Q. Tran T. N.P. Tran, Attitudes toward the use of project-based learning: A case study of Vietnamese High school students, Journal of Language and Education 6(3) (2020) 140-152. https://doi.org/10.17323/jle.2020.10109.

[4] J. Bergmann, J., \& A. Sams, Flip Your Classroom: Reach every student in every class every day. Washington, D.C.: International Society for Technology in Education, (2012), Available at: http://i-lib.imu.edu.my/NewPortal/images/ NewPortal/CompE-Books/Flip-YourClassroom.pdf.

[5] N. Hockly, ETpedia Technology, Hove, UK: Pavilion Publishing and Media, 2017.

[6] Part of the Cambridge Papers in ELT series, 2020, Cambridge University Press.

[7] I. Kostka, \& H. W. Marshall, Flipped Learning in TESOL: Past, Present, and Future. In Perren, J., Kelch, K., Byun, J., Cervantes, S., \& Safavi, S. (Eds.), Applications of CALL Theory in ESL and EFL Environments. Hershey, PA: IGI Global, (2017), 223-243.

[8] C. Johnson \& D. Marsh, The flipped classroom. In McCarthy, M. (Ed.), The Cambridge Guide to Blended Learning for Language Teaching. Cambridge: Cambridge University Press, 2016, 55-67.

[9] S. Mercer \& Z. Dörnyei, Engaging Language Learners in Contemporary Classrooms, Cambridge: Cambridge University Press, 2020.

[10] P. Ur, A Course in English Language Teaching, Cambridge: Cambridge University Press, 2012.
[11] E. Voss \& I. Kostka, Flipping Academic English Language Learning, Singapore: Springer, 2019.

[12] K. Fulton, Upside down and inside out : Flip your classroom to improve student learning, Learning \& Leading with Technology, 39(8), (1993), 1217.

[13] C. F. Herreid, \& N. A. Schiller, Case Studies and the Flipped Classroom, Journal of College Science Teaching, 2013, 42(5), 62-66.

[14] P. Benson, Autonomy and independence in language learning, London: Longman, 2007.

[15] L. Dickinson, Talking shop: Aspects of autonomous Learning: An interview with Leslie Dickinson, ELT Journal 47(1) (1993) 330-341.

[16] G. Murray, The social dimensions of learner autonomy and self-regulated learning. Studies in Self-Access Learning Journal 5(4) (2014) 320341. [14] L. Dam, Learner Autonomy 3: From Theory to Classroom Practice, Dublin: Authentik, 1995.

[17] N, Hockly \& G. Dudeney, Digital Learning in 2020, In Carrier, M., Damerow, R. M., \& Bailey, K. M. (Eds.), Digital Language Learning and Teaching. New York: Routledge, 2017, 235-245.

[18] O. S. Kvashnina, \& E. A. Martynko, Analyzing the potential of flipped classroom in ESL teaching, International Journal of Emerging Technologies in Learning, 11(3), (2016), 71-73. DOI: 10.3991/ijet.v11i03.5309.

[19] T, J. Bristol, Educate, excite, engage, Teaching and Learning in Nursing, 9, 2014, 43-46.

[20] J. Norris, The flipped classroom: For active, effective and increased learning - especially for low achievers. International Journal of Educational Technology in Higher Education (2016) 13:33 DOI 10.1186/s41239-016-0032-z 